\title{
Influence of the abilities in controlling violence behavior to the length of stay of schizophrenic clients in Bogor mental hospital, Indonesia
}

\author{
Budi Anna Keliat ${ }^{1}$, Azrul Azwar², Adang Bachtiar³, Achir Yani S. Hamid ${ }^{4}$ \\ 1 Faculty of Nursing University of Indonesia, Jakarta \\ ${ }^{2}$ Head of Health Science Institute Binawan, Formal Director General of Community Health in Ministry of Health Republic of Indonesia, \\ Jakarta \\ ${ }^{3}$ Head of Department of Administration and Policies in Faculty of Public Health, University of Indonesia; Lecture in Faculty of Public \\ Health University of Indonesia, Jakarta \\ ${ }^{4}$ Head of Department of Mental Health Nursing in Faculty of Nursing, The president of nurses association Indonesia,
}

\begin{abstract}
Abstrak
Tujuan Klien yang dirawat di rumah sakit jiwa di Indonesia mempunyai rerata lama hari rawat yang tinggi yatu 54 hari, dan yang paling lama dirawat adalah klien dengan diagnosa skizofrenia. Data rumah sakit jiwa pusat Bogor 2001, menunjukkan rerata lama hari rawat adalah 115 hari dan untuk klien perilaku kekerasan 42 hari. Penelitian ini bertujuan mengurangi lama hari rawat klien skizofrenia dengan perilaku kekerasan dengan meningkatkan kemampuan klien mencegah perilaku kekerasan.

Metoda Metoda penelitian yang digunakan adalah kuasi eksperimen dengan disain multipel seri ganda. Penelitian dilakukan di RSJP Bogor, dengan 152 responden (75 orang kelompok intervensi dan 77 orang kelompok non intervensi). Pendidikan diberikan kepada kelompok intervensi tentang cara mencegah perilaku kekerasan.

Hasil Dari hasil penelitian ditemukan bahwa rerata lama hari rawat klien kelompok intervensi adalah 23 hari dan kelompok non intervensi 40 hari. Klien kelompok intervensi yang mempunyai kemampuan mandiri 86,6\% dan kemampuan dengan bantuan 13,4\% dalam mencegah perilaku kekerasan. Klien kelompok non intervensi semuanya tidak mempunyai kemampuan mengendalikan perilaku kekerasan. Klien dengan kemampuan mandiri dalam mencegah perilaku kekerasan mempunyai lama hari rawat yang lebih pendek secara bermakna dibandingkan dengan klien yang tidak mempunyai kemampuan (p-value 0.025).
\end{abstract}

Kesimpulan Disimpulkan, pendidikan kesehatan tentang cara mencegah perilaku kekerasan dapat meningkatkan kemampuan klien dan selanjutnya memperpendek lama hari rawat secara bermakna. (Med J Indones 2009; 18: 31-5)

\begin{abstract}
Aim In average, the length of hospital stay in mental hospitals in Indonesia is 54 days, the longest of which occur on schizophrenic clients. In Bogor Mental Hospital, the average length of stay is 115 days. Those with schizophrenic and violence behavior have 42 days length of stay. The purpose of this study was to reduce length of stay for schizophrenic clients by enhancing their abilities to control violence behavior.

Methods This is a quasi experimental study with multiple series design. Study was conducted in Bogor Mental Hospital with 152 respondents (75 intervention and 77 non intervention). Training was given to the intervention group about the ways how to control violence behavior.

Results The results of this study showed that the average length of stay in the hospital for the clients in intervention group was 23 days and non intervention group was 40 days. There were $86.6 \%$ of clients in intervention group that independently (without assistance) could control their behavior, whereas $13.4 \%$ still need assistant. All clients in non intervention group had no abilities to control their violence behavior. Clients who were independent in controlling violence behavior had significantly shorter length of stay compared to non independent clients $(\mathrm{p}<0.05)$.

Conclusion Hence, the training control violence behavior can increase the abilities of the clients in controlling their violence behavior and resulting in shorter length of stay in hospital. (Med J Indones 2009; 18: 31-5)
\end{abstract}

Keywords: violence behavior, schizophrenia, training, length of stay.

Schizophrenia represents most common mental health problems and until recently remain unsolved in the world. The client and family have double burden which are the illness itself and stigma of schizophrenia. ${ }^{1}$ Schizophrenia is a combination of positive symptoms such as delusion, hallucination, disorganize speech, 
disorganize behaviors (violence behavior), catatonic, and negative symptoms such as lack of functions, flat/ dull affect, withdrawal, and no initiative. ${ }^{1,2,3,4}$ Research related to violence behavior found that medical diagnosis of clients with violence behavior consist of: $49 \%$ substance abuser, $45 \%$ schizophrenia, and $34 \%$ severe depression. ${ }^{5}$

Clients with mental disorders are often excommunicated and restricted because the society assumes that they are dangerous. Study conducted by The Canadian Mental Health Association $^{3}$ found that $88 \%$ respondents told that the clients were dangerous, $40 \%$ said they were retarded and $32 \%$ told they could not functioning However, 20-30\% of the clients could earn normal live, $20-30 \%$ showed symptoms and 40-60\% showed bad condition. Curing the clients with schizophrenia is possible, and maximal effort is needed.

Violence behavior consisted of violence to others, at self, to the environment, and verbally. ${ }^{11}$ Stuart and Laraia ${ }^{16}$ elaborated three strategies of nursing interventions for the clients with violence behaviors; which consist of: controlling, anticipation, and restraint. Strategy that was tested in this study was controlling strategy by providing training to the clients about how to control violence behavior. Four ways of controlling were taught, consisting of physical, verbal, spiritual and medication obedience.

Angry feeling can be sublimated through constructive physical activities by using power and energy. ${ }^{13,14,18}$ A physical relaxation activity such as deep breathing training is an alternative choice. ${ }^{4}$ In this study two physical ways was selected that more possible to be conducted; consisting of deep breath training, and beating pillow or mattress.

The most successful method in controlling violence behavior is by training how to speak assertively. ${ }^{16,17}$ Emotion atmosphere such as dislike, sulky, and anger are the conditions which can result in violence behavior. ${ }^{13}$ Expressing the feeling verbally and willing confidentially without threaten represent assertive ways., ${ }^{4}$ Direct communication training to others about deduction illogical request, telling complaints to others' attitudes, and giving praise to others can also control violence behavior. ${ }^{16}$ In this study we selected three ways to control violence behavior by verbal way, those were request assertively, refuse assertively, and express feeling assertively.

Clients desire to dominate and force others are considered as an immoral behaviors. ${ }^{14}$ For this case, clients was assisted to respect their spiritual values and beliefs concerning anger behaviour. Clients were helped to transform their willing to dominate others trough religious activities and invoking to control others and themselves. This maneuver was aimed to help the clients to do two religious activities that formerly conducted.

Antipsychotic medications given to the schizophrenia clients with violence behavior are effective to reduce violence behavior that is a positive symptom of schizophrenia. ${ }^{16}$ Combination of antipsychotic therapy and self-management are the nursing interventions for the clients and their families. ${ }^{6,8}$ In this research, clients were taught about medication management namely five right ways of taking medication: right name, right medicines, right doses, right frequency, and right routes. It was also explained the benefits of medication and effects of withdrawing from taking medication.

The main aim of this study was to know the relationship between client's abilities in controlling violence behavior and the length of stay in Bogor mental hospital.

\section{METHODS}

This study is a quasi experimental research with multiple series design, conducted in Bogor mental hospital, Indonesia.

Respondents were the clients with violence behavior who were diagnosed as schizophrenia, and hospitalized in Bogor Mental Hospital. Respondents were randomly grouped into intervention and non intervention. Total respondents were 152 clients consisted of 75 patients in intervention group and 77 in non intervention group.

Clients in intervention group were trained in four ways to control violence behavior.

After training, the daily activities were scheduled and practiced continuously until they were considered independent. The ability was measured daily and classified into three categories: "independent" if the clients are able to control violence behavior without reminding and help by others; "assistance" if clients are able to control violence behavior according to the schedule but need to be reminded; "dependent or unable" if clients could not control their violence behavior. The length of stay in the hospital was measured from admission day until they are discharged from the hospital. 
Research Ethic committee of Faculty of Medicine University of Indonesia has given Ethical Clearance for this study. Clients and their family have been provided information about the study and signed the informed consent form. Respondent's right were protected and all documents were kept confidential and cannot be accessed by others except the researchers.

Characteristic of clients, abilities to control violence behavior and length of stay in hospital were analyzed with univariate method using frequency distribution. Relationship between clients characteristic and hospitalization length were analyzed with bivariate using paired t-test and ANOVA. The length of stay according to the ability to control violence behavior and was tested by using ANOVA.

\section{RESULTS}

Characteristics of intervention groups and non intervention groups can be seen in Table 1. Both groups were equal except in level of education, where the intervention group has significantly higher education level $(p<0.05)$ than non intervention group. Background education was not significant related with the length of stay.

Table 1. Characteristics of respondents with violence behaviors

\begin{tabular}{|c|c|c|c|c|c|}
\hline \multirow{3}{*}{$\begin{array}{l}\text { Characteristics of } \\
\text { Respondents }\end{array}$} & \multicolumn{4}{|c|}{ Categories of Respondents } & \multirow{3}{*}{ p-value } \\
\hline & \multicolumn{2}{|c|}{ Intervention } & \multicolumn{2}{|c|}{$\begin{array}{c}\text { Non } \\
\text { Intervention }\end{array}$} & \\
\hline & $\mathbf{N}$ & $\%$ & $\mathrm{n}$ & $\%$ & \\
\hline \multicolumn{6}{|l|}{ Sex } \\
\hline - Male & 54 & 72.0 & 50 & 64.9 & \multirow{2}{*}{0.349} \\
\hline - Female & 21 & 8.0 & 27 & 35.1 & \\
\hline \multicolumn{6}{|l|}{ Age } \\
\hline - $\leq 30$ years & 48 & 62.3 & 47 & 63.5 & \multirow{3}{*}{0.581} \\
\hline - $31-40$ years & 23 & 29.9 & 21 & 28.4 & \\
\hline - $>40$ years & 6 & 7.8 & 6 & 8.1 & \\
\hline \multicolumn{6}{|l|}{ Position in Sibling } \\
\hline - First & 22 & 9.3 & 22 & 28.6 & \multirow{5}{*}{0.890} \\
\hline - Second & 15 & 20.0 & 18 & 23.4 & \\
\hline - Third & 17 & 22.7 & 14 & 18.2 & \\
\hline - Fourth+ & 21 & 28.0 & 23 & 29.8 & \\
\hline \multicolumn{5}{|l|}{ Education } & \\
\hline \multicolumn{6}{|l|}{ Background } \\
\hline - Low & 23 & 30.7 & 36 & 46.8 & \multirow{3}{*}{0.036} \\
\hline - Mid & 33 & 44.0 & 33 & 42.8 & \\
\hline - High & 18 & 25.3 & 8 & 10.3 & \\
\hline \multicolumn{6}{|l|}{ Job } \\
\hline - Jobless & 43 & 57.3 & 49 & 63.6 & \multirow{2}{*}{0.427} \\
\hline - Work & 32 & 42.7 & 28 & 36.4 & \\
\hline \multicolumn{6}{|l|}{ Marital Status } \\
\hline - Married & 24 & 32.0 & 29 & 37.7 & \multirow{2}{*}{0.464} \\
\hline - Unmarried & 51 & 68.0 & 48 & 62.3 & \\
\hline
\end{tabular}

\section{Ability in controlling violence behaviors}

It was found that $86.6 \%$ of intervention group had independent abilities in controlling violence behavior, while all non interventions group was dependent or unable to control their violence behavior (Table 2).

Table 2. The ability of clients in controlling violence behaviors in intervention and non intervention groups

\begin{tabular}{|c|c|c|c|}
\hline \multirow{2}{*}{$\begin{array}{c}\text { The Abilities to } \\
\text { Control Violence } \\
\text { Behavior }\end{array}$} & \multicolumn{2}{|c|}{ Categories of Respondents } & \multirow{2}{*}{ Total } \\
\hline & Intervention & $\begin{array}{c}\text { Non } \\
\text { Intervention }\end{array}$ & \\
\hline \multicolumn{4}{|l|}{ Physical way } \\
\hline - Independent & 65 & 0 & 65 \\
\hline - With Assistance & 10 & 0 & 10 \\
\hline - Dependent & 0 & 77 & 77 \\
\hline \multicolumn{4}{|l|}{ Social Way } \\
\hline - Independent & 62 & 0 & 62 \\
\hline - With Assistance & 13 & 0 & 13 \\
\hline - Dependent & 0 & 77 & 77 \\
\hline \multicolumn{4}{|l|}{ Spiritual Way } \\
\hline - Independent & 44 & 0 & 44 \\
\hline - With Assistance & 31 & 0 & 31 \\
\hline - Dependent & 0 & 77 & 77 \\
\hline \multicolumn{4}{|l|}{$\begin{array}{l}\text { Medication } \\
\text { Obedience }\end{array}$} \\
\hline - Independent & 44 & 0 & 44 \\
\hline - With Assistance & 31 & 0 & 31 \\
\hline - Dependent & 0 & 77 & 77 \\
\hline \multicolumn{4}{|l|}{ Composite } \\
\hline - Independent & 42 & 0 & 42 \\
\hline - With Assistance & 33 & 0 & 33 \\
\hline - Dependent & 0 & 77 & 77 \\
\hline
\end{tabular}

\section{Length of stay in the hospital}

The average length of stay in the hospital in intervention group was 23 days and in non intervention group was 40 days and the difference was significant $(p<0.05)$.

Table 3. Distribution of the clients with violence behaviors based on the length of stay in hospital

\begin{tabular}{lcc}
\hline \multicolumn{1}{c}{$\begin{array}{c}\text { Categories of } \\
\text { Respondents }\end{array}$} & $\begin{array}{c}\text { Average } \\
\text { Length of Stay }\end{array}$ & p-value \\
\hline $\begin{array}{l}\text { Intervention Group } \\
(\mathrm{n}=75)\end{array}$ & 22,51 & $\mathbf{0 . 0 0 2}$ \\
$\begin{array}{l}\text { Non Intervention Group } \\
(\mathrm{n}=77)\end{array}$ & 40,16 & \\
\hline
\end{tabular}




\section{Relationship Between Client's Characteristics and the Length of Stay in Hospital}

Characteristic of age has relationship with the length of hospitalization significantly $(p<0.05)$ (Table 3$)$. It means that the older the clients had the longer of their hospitalization.

Table 3. Relationship between characteristics of clients with violence behavior and the length of stay

\begin{tabular}{|c|c|c|}
\hline $\begin{array}{c}\text { Characteristic of } \\
\text { Clients }\end{array}$ & $\begin{array}{c}\text { Average } \\
\text { Length of Stay }\end{array}$ & p-value \\
\hline \multicolumn{3}{|l|}{ Sex } \\
\hline - Male & 27.86 & \multirow{2}{*}{0.069} \\
\hline - Female & 39.23 & \\
\hline \multicolumn{3}{|l|}{ Age } \\
\hline - $\leq 30$ years & 26.02 & \multirow{3}{*}{0.019} \\
\hline - 31-40 years & 47.17 & \\
\hline - $>40$ years & 28.55 & \\
\hline \multicolumn{3}{|l|}{ Position in Sibling } \\
\hline - First & 29.89 & \multirow{4}{*}{0.743} \\
\hline - Second & 34.03 & \\
\hline - Third & 29.39 & \\
\hline - $\geq$ Fourth & 32.52 & \\
\hline \multicolumn{3}{|l|}{$\begin{array}{l}\text { Education } \\
\text { Background }\end{array}$} \\
\hline - Low & 30.07 & \multirow{3}{*}{0.816} \\
\hline - Medium & 31.26 & \\
\hline - High & 35.46 & \\
\hline \multicolumn{3}{|l|}{ Job } \\
\hline - Work & 30.30 & \multirow{2}{*}{0.628} \\
\hline - Jobless & 33.20 & \\
\hline \multicolumn{3}{|l|}{ Marital Status } \\
\hline - Married & 34.53 & \multirow{2}{*}{0.440} \\
\hline - Unmarried & 29.80 & \\
\hline
\end{tabular}

The relationship between abilities to control violence behavior and the length of hospitalization

The results of this study showed that clients who were independent had significantly shorter length of stay compared to those who are dependent or unable $(\mathrm{p}<$ 0.05) (Table 4).
Table 4. The relationship between ability to control violence behavior and the length of stay in the hospital

\begin{tabular}{lcc}
\hline \multicolumn{1}{c}{$\begin{array}{c}\text { Abilities to } \\
\text { Control }\end{array}$} & $\begin{array}{c}\text { Average } \\
\text { Length of Stay }\end{array}$ & p-value \\
\hline $\begin{array}{l}\text { Physical way } \\
\text { - Independent }\end{array}$ & 21.30 & \\
- With Assistance & 30.20 & $\mathbf{0 . 0 3 9}$ \\
- Dependent & 40.16 & \\
Social Way & & \\
- Independent & 22.87 & \\
- With Assistance & 20.77 & \\
- Dependent & 40.16 & $\mathbf{0 . 0 1 4}$ \\
Spiritual Way & & \\
- Independent & 22.48 & \\
- With Assistance & 22.70 & \\
- Dependent & 40.16 & \\
Medication & & \\
Obedience & & \\
- Independent & 22.16 & $\mathbf{0 . 0 1 1}$ \\
- With Assistance & 23.00 & $\mathbf{0 . 0 0 9}$ \\
- Dependent & 40.16 & \\
Composite & & \\
- Independent & 22.31 & \\
- With Assistance & 26.60 & \\
- Dependent & 40.16 & \\
\hline
\end{tabular}

\section{DISCUSSION}

About $47 \%$ approaches for violence clients used medicine, restraint or seclusion. ${ }^{16}$ The way to control violence had been thought to the clients by using physical, social or interaction, spiritual and medication. Nursing staff must motivate a patient and make him or her continue learning to verbalize his or her feeling, ${ }^{17}$ this was one of the way have been thought to the client to control violence.

The result of this study showed that the length of hospital stay of clients who were independent in managing medication is shorter than another. There is good evidence to show that people with mental illness who are receiving treatment are no more likely to perpetrate violence than people in general. The risk that someone treated for schizophrenia, for instance, of harming or killing another person is almost exactly the same as for the general population. In fact, people with mental illness, according to research, are more than twice as likely to be the victims of violence than the general population. ${ }^{18}$ 
The average length of hospital stay in clients receiving training to control violence behavior was 23 days and who were not trained was 40 days. This result gives an advantage for clients and their families because the expense of hospitalization can decrease by 17 days and the quality of life become better due to increase in residing at home compared to staying in the hospital. Length of stay was shorter than the average length of stay clients at mental hospitals in Indonesia, i.e 54 days ${ }^{1}$. In Bogor Mental Hospital as a whole the average length of stay is 115 days and specific for clients with violence behavior, it is 42 days. ${ }^{2}$ The decreased length of hospital stay and the improved psychosocial functioning in client resulted in a marked overall cost saving. ${ }^{19}$

Although have been better than the length of hospitalization in Indonesia, it is not yet equal to that in other countries as reported by Morrison, ${ }^{3}$ where the length of stay in the hospital of the client with violence behavior was only 14 days. The latest study by Boyd and Nikart ${ }^{5}$, Boyd $^{6}$, found that the length of stay in the hospital varied from less than 7 days (brief short term), 7-14 days (very short term), 15-21 days (traditional short term), and $>21-120$ days (long term care). Trained clients who were independent in controlling violence behavior were $86.6 \%$. This proves that clients with mental disorders still have self-care abilities, and there is still hope to improve their function. This finding could change public opinion that schizophrenic clients cannot function anymore.

The clients who were hospitalized for seven weeks or longer were 49 per cent less likely to be readmitted within a month compared to those who stayed only a week. ${ }^{20}$ Control and intervention group had length of hospital stays between 23 days -40 days ( 3 weeks to 5.5 weeks), those had possibility for readmission within 30 days. There were many way to manage schizophrenia with violence, which could reduce more the length of hospital stays. ${ }^{21}$

It is concluded that clients who were independent in controlling violence behavior had a significant shorter length of hospitalization than clients who were dependent in controlling violence behavior. Males had shorter length of hospital stay significantly than females. Moreover, in the frequency of admission, the clients who were hospitalized once or twice have significantly shorter length of hospital stay than the clients who were hospitalized in third times or more.

\section{REFERENCES}

1. Johnson BS. Psychiatric-mental health nursing: adaptation and growth. (4 ${ }^{\text {th }}$ ed). Philadelphia : JB Lippincott Company, 1997.p.764-91.

2. Boyd MA, Nikart MA. Psychiatric nursing contemporary practice. Philadelphia: Lippincott, 1998.p.360-402.

3. Boyd MA. Psychiatric nursing: contemporary practice. Philadelphia, Lippincott \& Wilkins, 2005.p.230-62.

4. Kaplan HI, Sadock BJ, Grebb J. A. Synopsis of psychiatry: behavioral sciences clinical psychiatry. $\left(10^{\text {th }} \mathrm{ed}\right.$.). Baltimore: Williams \& Wilkins, 2007.p.1329-558.

5. Morison EF. The evolution of a concet: aggression and violence in psychiatric settings. Archieves of Psychiatric Nursing, Vol. III, No. 4 (August): p.245-53.

6. Stuart GW, Laraia MT. Principles practice psychiatric nursing $\left(7^{\text {th }}\right.$ ed). St.Louis: Mosby, 2005.p.639-52.

7. Puckett A. Community mental health. Sydney: WB Saunders, 1993.p.223-50.

8. Rawlins RP, Williams SR, Beck CK. Mental healthpsychiatric nursing: a holistic life-cycle approach. St. Louis: Mosby Year Book, 1993.p.207-23.

9. Videbeck SL. Psychiatric mental health nursing. Philadelphia: Lippincott, 2001.p.214-27.

10. Davis M, Eshelman ER, Mc. Kay M. Panduan relaksasi \& reduksi stress. Alih bahasa: Hamid AYS. and Keliat BA. Jakarta: ECG, 1995.

11. Townsend MC. Essentials of psychiatric mental health nursing ( $3^{\text {rd }}$ ed). Philadelphia: FA Davis Company, 2005.

12. Drake RE, Mueser KT, Torrey WC, Miller AL, Lehman AF, Bond GR, Goldman HH, LeffHS. Evidence-based treatment of skizophrenia. Curr Psychiatry Rep. 2000; 2(5):393-7.

13. Gibson DM. Reduced rehospitalizations and reintegration of persons with mental illness into community living: a holistic approach. Journal Psychosocial Nursing Mental Health Service, 1999; 37(11): 20-5.

14. Duxbury J. An evaluation of staff and patient views of and strategies employed to manage inpatient aggression and violence on one mental health unit: a pluralistic design. Journal of Psychiatric and Mental Health Nursing. 2002;9:325-37.

15. Toshiko M. Nursing care of schizophrenic patient who impulsively repeats violence: the case in which violence decreased by verbalizing feelings. Nippon Seijinkai Suda Hospital. 2005; 48(1):194-5.

16. Understanding mental illness and violence. Available at: www.mifsa.org.au Accessed August 19 2008.

17. Depkes RI, Dirjen Yanmed. Informasi rumah sakit. Jakarta: Depkes RI. 2000.

18. Rumah Sakit Jiwa Pusat Bogor. Laporan akuntabilitas kinerja RSJP Bogor years Anggaran 2001. Bogor: Not publish, 2001.

19. Hirayasu Y, Korn ML. Management of patient with acute psychosis. CME. Available at: www.medscape.com/ viewarticle/420241. Accessed December $4^{\text {th }} 2008$.

20. Hospital length of stay and readmission for individuals diagnosed with schizophrenia: Are they related. Available at: www.cihi.ca. Accessed January $8^{\text {th }}, 2009$

21. Thomson LDG. Management of schizophrenia in condition of high security. Advanced in Psychiatric Treatment. 2000; 6: $252-60$. 